\title{
Improved procedures for extraction of water-extractable carbohydrates from particulate organic matter
}

\author{
Didier BURDLOFF ${ }^{*}$, Henri ETCHEBER ${ }^{a}$, Roselyne BUSCAIL ${ }^{b}$ \\ ${ }^{a}$ Département de géologie et océanographie, université Bordeaux-I, UMR-CNRS 5805, avenue des Facultés, \\ 33405 Talence cedex, France \\ ${ }^{\mathrm{b}}$ Centre de formation et de recherche sur l'environnement marin, UMR CNRS 5110, université de Perpignan, \\ 52, avenue de Villeneuve, 66860 Perpignan, France
}

Received 2 March 2001; revised 28 May 2001; accepted 29 May 2001

\begin{abstract}
The present work presents improvements to the existing methods for extraction of carbohydrates with water. In order to test the effects of extraction factors on the yield of carbohydrates, extractions of water-soluble carbohydrates were performed with two contrasting samples (suspended particulate organic matter from the high turbidity zone of the Gironde estuary and sedimentary organic matter from the Arcachon lagoon) under different experimental conditions. Results show that: (i) boiling water applied for 30 min yielded the best result for water-soluble carbohydrates in both samples; (ii) sonic disruption had a strong influence on the recovery rate of water-soluble carbohydrates - a steady yield was reached after a 3-min treatment; (iii) almost all the water-extractable carbohydrates are removed after the third extraction. Consequently, a general method is proposed to improve the extraction of water-extractable carbohydrates from particulate matter. (C) 2001 Ifremer/CNRS/IRD/Éditions scientifiques et médicales Elsevier SAS
\end{abstract}

Résumé - Amélioration de la procédure d'extraction des carbohydrates soluble dans l'eau de la matière organique particulaire. Sur la base de deux échantillons organiques de nature opposée (matières en suspension de la zone de maximum de turbidité de l'estuaire de la Gironde et sédiments du bassin d'Arcachon), on a pu évaluer les effets de différents facteurs d'extraction sur la méthode d'extraction des sucres par l'eau. Ainsi, le rendement d'extraction des sucres solubles devient optimum (i) lorsque l'extraction est conduite à $100^{\circ} \mathrm{C}$ et dans une période minimale de 30 min ; (ii) lors de l'application d'un traitement aux ultrasons de $3 \mathrm{~min}$; (iii) après trois extractions successives. Une optimisation de l'extraction des sucres solubles est alors proposée en vue de l'harmonisation des méthodes d'extraction. (C) 2001 Ifremer/CNRS/IRD/Éditions scientifiques et médicales Elsevier SAS

extraction factors / particulate organic matter / water-soluble carbohydrates

facteurs d'extraction / matière organique particulaire / sucres solubles

*Correspondence and reprints: fax: +33 556840848.

E-mail address: burdloff@geocean.u-bordeaux.fr (D. BURDLOFF). 


\section{INTRODUCTION}

Carbohydrates play an important role in biogeochemical cycles occurring in the marine water column and watersediment interface (Hedges et al, 1994; Moers et al al, 1994: Arnosti_and_Holmer_1999). Carbohydrates are the most abundantly produced photosynthetical compounds in waters due to the predominance of structural polysaccharides including cellulose, hemicellulose and pectin in plants (Aspinall_ 1983). Carbohydrates also are major storage compounds in autotrophic organisms and play critical roles in cellular metabolism Sakmgawa and Handa. 1985: Hama and Handa. 1992: Opsahl and Benner, 1999.

There are two different reliable ways of determining carbohydrate contents in particulate organic matter: (i) through the hydrolised fraction by various and strong acids (such as $\mathrm{HCl}, \mathrm{H}_{2} \mathrm{SO}_{4}$ and PTSA) corresponding to the total carbohydrate reserves: structural polysaccharides and storage sugars Buscail et al. 1995: Kerhervé et Gl. 1995: Buscail and Germain. 1997: Opsahl and Benher. 1999): (ii) or through the storage glucan which can be easily extracted by water (Dawson et al. 1983: Hama and Handa, 1992; Etcheber et al. 1999: Burdloff et al. 2000)

Associated to both easily extractable proteins and lipids, water-soluble carbohydrates are thought to be the most degradable part of particulate organic matter and are thus selected as suitable tools for achieving a good understanding of the effect of nutritional quality of particulate matter on biological processes Lelexans et al. 1992a. 1992b: Navarro et al. 1993; Danovaro et al. 1995: Etcheber et al. 1999: Burdloff et al. 2000). Numerous experimental schemes have been developed, especially concerning extraction of water-soluble carbohydrates procedures table 1 . The fundamental differences be- tween them lies in the choice of the duration and number of extractions and this makes it very difficult to compare the various published results. However, no estimate of the impact of sonic disruption on the yield of waterextractable carbohydrates has been realised to date. In their study of easily extractable lipids of recent sediments, Farrington and Quinn (1971) observed that sonic disruption improved the yield of fatty acid from 60 to $70 \%$. Rausch (1981) also reported that sonic disruption increased extraction of micro-algal proteins. As yet, very little attention has been given to the effects of extraction factors on the yield of water-soluble carbohydrates.

The purpose of this work is therefore to assess the effects, on the yield of water-soluble carbohydrates, of temperature, duration and number of extractions, and to determine the best moment and duration for sonic disruption. The results are based upon the comparison of two contrasting samples: a weakly degradable organic matter sample (the maximum turbidity zone of the Gironde estuary, France) and a highly degradable one (the Arcachon lagoon, France). An extraction procedure capable of leading to an optimal extraction of watersoluble carbohydrates of organic matter is then proposed.

\section{MATERIALS AND METHODS}

The Gironde estuary is characterised both by a long residence time of water and particles within the estuary and by the occurrence of a maximum turbidity zone Sottolichio and Castaing. 1999 whose degradable organic fraction represents 5 to $10 \%$ of particulate organic matter, emphasising the detrital nature of organic matter Lin and Etcheber. 1994: Burdloff et al.. 2000. Eightyfive per cent of the particles have a diameter of less

Table I. Comparison of main extraction methods for water-soluble carbohydrates determination.

\begin{tabular}{llcll}
\hline Material & Solvent & Temperature $\left({ }^{\circ} \mathrm{C}\right)$ & Time & References \\
\hline Marine sediment & $\mathrm{H}_{2} \mathrm{O}$ & 100 & $10 \mathrm{~min}$ & Etcheber et al., 1999 \\
& $\mathrm{H}_{2} \mathrm{O}$ & 100 & $10 \mathrm{~min}$ & Relexans et al., 1992a, 1992b \\
Suspended particulate matter & $\mathrm{H}_{2} \mathrm{O}$ & 100 & $20 \mathrm{~min}$ & Delmas, 1983 \\
& $\mathrm{H}_{2} \mathrm{O}(\times 2)$ & 100 & $1 \mathrm{~h}$ & Hama and Handa, 1992 \\
& $\mathrm{H}_{2} \mathrm{O}(\times 2)$ & 100 & $1 \mathrm{~h}$ & Handa and Yanagi, 1969 \\
& $\mathrm{H}_{2} \mathrm{O}(\times 2)$ & 100 & $30 \mathrm{~min}$ & Sakugawa and Handa, 1985 \\
& $\mathrm{H}_{2} \mathrm{O}$ & 80 & $4 \mathrm{~h}$ & Dawson et al., 1983 \\
& $\mathrm{H}_{2} \mathrm{O}$ & 100 & $3 \mathrm{~h}$ & Rho and Litsky, 1979 \\
& $\mathrm{H}_{2} \mathrm{O}$ & 100 & $1 \mathrm{~h}$ & Smetacek and Hendrikson, 1979 \\
\hline
\end{tabular}


than $<16 \mu \mathrm{m}$ and among them $50 \%$ are clay minerals of terrestrial origin (Weber et al. 1991). Sampling was carried out in this maximum turbidity zone $\left(1 \mathrm{~g} \cdot \mathrm{L}^{-1}\right)$ at a 1 -m water depth. Immediately after the collection, water samples were filtered through precombusted $\left(450{ }^{\circ} \mathrm{C}\right.$, $4 \mathrm{~h}$ ) glass fibre filters (Whatman GF/F) to collect suspended particulate matter.

For 20 years, the Arcachon lagoon has displayed various nitrogen eutrophication signs predominantly influenced by intensive agricultural practices (maize cultivation) (Rimmelin et al. 1998) As a result, the degradable sedimentary organic fraction accounts for 20 to $40 \%$ of the organic matter (Relexans et al. 1992a). The upper first centimetres of the sediment samples were taken in a Zostera noltii seagrass bed, located in the intertidal area from the intermediate part of the lagoon.

Particulate matter from each area was dried at $40{ }^{\circ} \mathrm{C}$ to constant weight before treatment and hand-grounded with a mortar.

Five major extraction factors have been tested on particulate matter to extract water-soluble carbohydrates: temperature, duration and number of extraction; the best moment and duration for sonic disruption. The solid residue was separated from the extract by centrifugation and rinsed twice with water $(5 \mathrm{~mL})$. The combined extracts and rinses were evaporated to a small volume $(10 \mathrm{~mL})$ and analysed. Total water-extractable carbohydrates were determined from an aliquot $(1 \mathrm{~mL})$ of the different water-extractable fractions, by the phenolsulphuric acid method Dubois et al. 1956 using glucose as the standard. The coefficient of variation (standard deviation/mean) of water-soluble carbohydrates by repeated analysis $(n=3)$ with spectrophotometer was $2 \%$. All the extractions were made in duplicate and each analysis of water-soluble carbohydrates was done in triplicate.

\section{RESULTS AND DISCUSSION}

Water-extractable carbohydrates are found in much lower quantity $(\sim 10$-fold $)$ in the Gironde estuary $\left(\sim 1300 \mu \mathrm{g} \cdot \mathrm{g}^{-1}\right)$ than in the Arcachon lagoon $\left(\sim 15000 \mu \mathrm{g} \cdot \mathrm{g}^{-1}\right)$. In the latter, large dissolved inorganic nitrogen inputs have significantly contributed to a succession of excessive vegetal growths representing an important potential source of carbohydrates. In contrast,

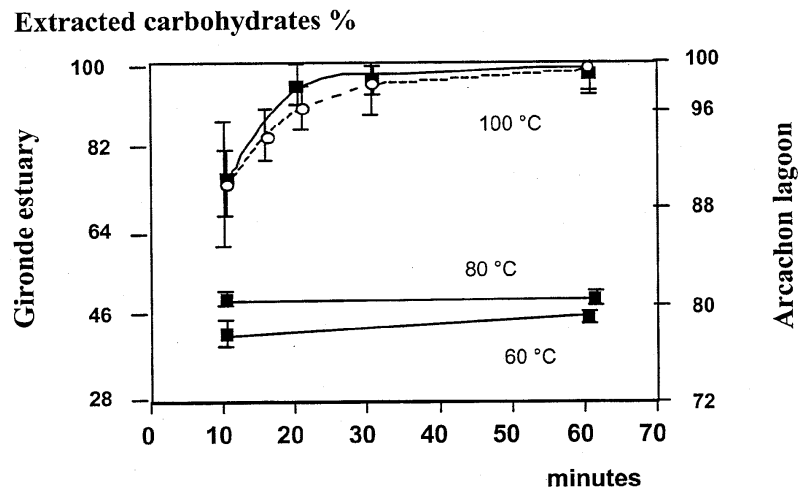

Figure 1. Average water-extractable carbohydrate yield (\%) of particulate matter collected from the maximum turbidity zone of the Gironde estuary (solid line) and the Arcachon lagoon (dashed line) and as a function of temperature and duration of extraction. Dots and vertical bars represent arithmetical means with confidence intervals given for a level of $95 \%$.

because large amounts of suspended particles limit light penetration, the maximum turbidity zone is characterised by significant heterotrophic processes and a very low phytoplankton production, inducing a mainly refractory organic matter Urigoien and Castel, 1997; Artigas, 1998: Burdloff et al.2000)

Water-soluble carbohydrate yields were positively correlated with temperature of extraction (fogure 1 ). The highest average water-soluble carbohydrate yields were achieved with the highest temperature $\left(100^{\circ} \mathrm{C}\right)$. In both samples, boiling water-extractable carbohydrate yields were optimal after the first $30 \mathrm{~min}$ of extraction. After this time, no significant difference was observed (Student's $t$-test; $P<0.05)$. We therefore conclude that optimal yield of water-extractable carbohydrates is reached after the first $30 \mathrm{~min}$ by boiling water. Consequently, any watersoluble carbohydrate extractions that may use lesser extraction conditions (under $100^{\circ} \mathrm{C}$ and/or for less than $30 \mathrm{~min}$ ) would lead to underestimate the water-soluble carbohydrate content (e.g. of up to $55 \%$ for extraction at $80{ }^{\circ} \mathrm{C}$ from organic matter of the Gironde estuary).

Experiments concerning sonic disruption effects have shown that, in both samples, larger amounts of watersoluble carbohydrates were recovered when sonic disruption took place at the end of extraction by boiling water for $30 \mathrm{~min}$, than before the boiling water extraction (figure 2). On the other hand, experiments on the duration of sonic disruption showed that water-soluble carbohydrate yields increased strongly between 0 (without sonic 


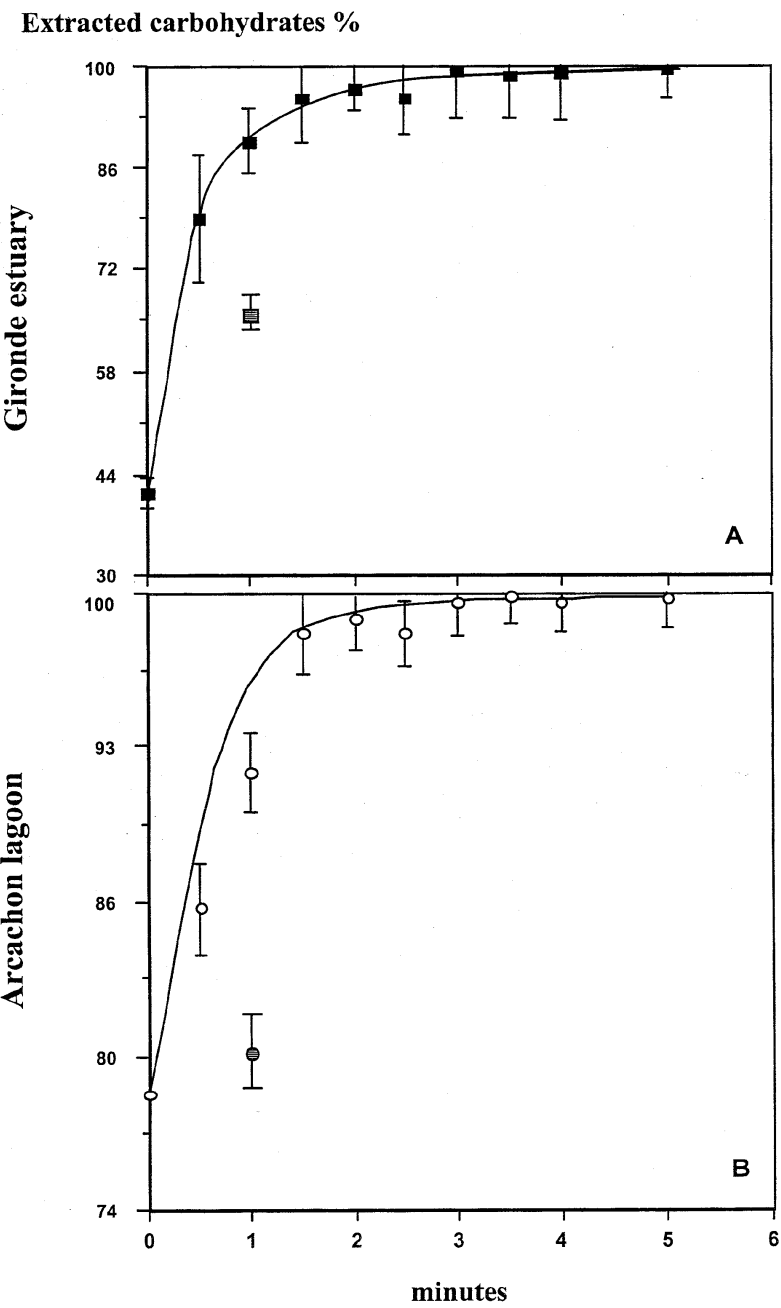

Figure 2. Average yields of water-soluble carbohydrates (\%) from particulate matter collected from the maximum turbidity zone of the Gironde estuary (A) and the Arcachon lagoon (B) and as a function of the best moment and duration for sonic disruption. Sonic disruptions were performed before (hatched symbols) and after (open and black symbols) extraction by boiling water for $30 \mathrm{~min}$. Dots and vertical bars represent arithmetical means with confidence intervals given for a level of $90 \%$.

disruption) and 2 min (foure 2). After 3 min of sonic disruption, steady yields were reached in both samples, corresponding to a supply of 60 and $22 \%$ of additional water-soluble carbohydrates for the maximum turbidity zone of the Gironde estuary and the Arcachon lagoon samples, respectively. These results indicate that although the water-soluble carbohydrate abundance in the maximum turbidity zone is lower than in the Arcachon lagoon, sonic disruption showed a more limited influence for the
Arcachon lagoon sediments than for the Gironde estuary samples. Water-soluble carbohydrates from mainly phytodetritus and seagrass origin are easily extracted in the Arcachon lagoon samples, while sonic disruption can probably reach water-soluble carbohydrates linked to clay minerals from the maximum turbidity zone samples.

A study of the efficiency of successive extractions on the yields of water-soluble carbohydrates indicates that 50 and $60 \%$ of water-soluble carbohydrates were yielded from the first extraction for the Gironde estuary and the Arcachon lagoon samples, respectively. The second extraction accounted for 20 to $25 \%$ of these compounds. Finally, only the third and the fourth extraction display very low values (around $5 \%$ of these compounds), indicating that almost all the water-extractable carbohydrates were removed after the third extraction.

\section{CONCLUSION}

Our results highlight the influence of different extraction protocols on the yield of water-extractable carbohydrates. For both contrasting organic matrices, a common method gave optimal yields of water-extractable carbohydrates: three successive extractions in boiling water for $30 \mathrm{~min}$ followed by $3 \mathrm{~min}$ of sonic disruption. Comparison with existing methods (table $)$ shows that our procedure differs from others mainly by the use of sonic disruption. This step clearly improves the watersoluble carbohydrate yields from 22 to $60 \%$, according to the organic matrix. The results of these experiments emphasise the absolute necessity of using rigorous and similar extraction procedures, in order to achieve optimal yields and valid comparisons of published results from various authors.

\section{Acknowledgements}

We are grateful to Catherine Goyet, Claire Tissandier and Ionna Bouloubassi for their comments which greatly helped improve the manuscript. This paper is Bordeaux I University DGO, UMR CNRS 5805 contribution No. 1405.

\section{REFERENCES}

Arnosti, C., Holmer, M., 1999. Carbohydrate dynamics and contributions to the carbon budget of an organic-rich coastal sediment. Geochim. Cosmochim. Acta 63, 393-404. 
Artigas, L.F., 1998. Seasonal variability in microplankton biomases in the Gironde dilution plume (Bay of Biscay): relative importance of bacteria. Oceanol. Acta 21, 563-580.

Aspinall, G.O., 1983. Polysaccharides. Academic Press, New York.

Burdloff, D., Gasparini, S., Sautour, B., Etcheber, H., Castel, J., 2000. Is the copepod egg production in a highly turbid estuary (the Gironde, France) a function of the biochemical composition of seston. Aquat. Ecol. 34, 165-175.

Buscail, R., Germain, C., 1997. Present-day organic matter on the NW Mediterranean margin: importance of off-shelf export. Limnol. Oceanogr. 42, 217-229.

Buscail, R., Pocklington, R., Germain, C., 1995. Seasonal variability of the organic matter in a sedimentary coastal environment: sources, degradation and accumulation (Continental shelf of the Gulf of Lions - northwestern Mediterranean Sea). Cont. Shelf Res. 15, 843-869.

Danovaro, R., Fabiano, M., Alberttelli, G., Della Croce, N., 1995. Vertical distribution of meiobenthos in bathyal sediments of the eastern Mediterranean Sea: relationship with labile organic matter and bacterial biomasses. Mar. Ecol. 16, 103-116.

Dawson, R., Liebezeit, G., Josefsson, B., 1983. Determination of amino acids and carbohydrates. In: Grasshoff, K., Ehrhardt, M., Kremling, K. (Eds.), Methods of Sea Water Analysis, 2nd ed. Verlag Chemie, Kiel, pp. 319-346.

Delmas, D., 1983. Les glucides et l'évolution de la matière organique dans les sédiments marins. Oceanol. Acta 6, 157-165.

Dubois, M., Gilles, K.A., Hamilton, J.K., Rebers, P.A., Smith, F., 1956. Colorimetric method for determination of sugars and related substances. Anal. Chem. 28, 350-356.

Etcheber, H., Relexans, J.C., Beliard, M., Weber, O., Buscail, R., Heussner, S., 1999. Distribution and quality of sedimentary organic matter on the Aquitanian margin (Bay of Biscay). Deep-Sea Res. 46, 2249-2288.

Farrington, J.W., Quinn, J.G., 1971. Comparison of sampling and extraction techniques for fatty acids in recent sediments. Geochim. Cosmochim. Acta 35, 735-741.

Hama, J., Handa, N., 1992. Diel variation of water-extractable carbohydrate composition of natural phytoplankton populations in Kinuura Bay. J. Exp. Mar. Biol. Ecol. 162, 159-176.

Handa, N., Yanagi, K., 1969. Studies on water-extractable carbohydrates of the particulate matter from the northwest Pacific Ocean. Mar. Biol. 4, 197-207.

Hedges, J.I., Cowie, G.L., Richey, J.E., Quay, P.D., Benner, R., Strom, M., Forsberg, B.R., 1994. Origins and processing of organic matter in the Amazon River as indicated by carbohydrates and amino acids. Limnol. Oceanogr. 39, 743-761.

Irigoien, X., Castel, J., 1997. Light limitation and distribution of chlorophyll pigments in a highly turbid estuary: the Gironde (SW France). Estuar. Coast. Shelf Sci. 44, 507-517.
Kerhervé, P., Charrière, B., Gadel, F., 1995. Determination of marine monosaccharides by high-pH anion-exchange chromatography with pulsed amperometric detection. J. Chromatogr. 718, 283-289.

Lin, R.G., Etcheber, H., 1994. The degradability of particulate organic matter in the Gironde Estuary, France. Chin. J. Oceanol. Limnol. 12, 106-113.

Moers, M.E.C., De Leeuw, J.W., Baas, M., 1994. Origin and diagenesis of carbohydrates in ancient sediments. Org. Geochem. 21, 1093-1106.

Navarro, J.M., Clasing, E., Urrutia, G., Asencio, G., Stead, R., Herrera, C., 1993. Biochemical composition and nutritive value of suspended particulate matter over a tidal flat of southern Chile. Estuar. Coast. Shelf Sci. 37, 59-73.

Opsahl, S., Benner, R., 1999. Characterization of carbohydrates during early diagenesis of five vascular plant tissues. Org. Geochem. 30, 83-94.

Rausch, T., 1981. The estimation of micro-algal protein content and its meaning to the evaluation of algal biomass. I - Comparison of methods for extracting protein. Hydrobiologia 78, 237-251.

Relexans, J.C., Lin, R.G., Castel, J., Etcheber, H., Laborde, P., 1992a. Benthic respiratory potential with relation to sedimentary carbon quality in seagrass beds and oyster parks in the tidal flats of Arcachon Bay, France. Estuar. Coast. Shelf Sci. 34, 157-170.

Relexans, J.-C., Etcheber, H., Castel, J., Escaravage, V., Auby, I., 1992b. Response of biota to sedimentary organic matter quality of the West Gironde mud patch, Bay of Biscay (France). Oceanol. Acta 15, 639-649.

Rho, J., Litsky, W., 1979. Cellulose production by planktonic algae in lacustrine environments. Hydrobiologia 66, 249-258.

Rimmelin, P., Dumon, J.-C., Maneux, E., Gonçalves, A., 1998. Study of annual and seasonal dissolved inorganic nitrogen inputs into the Arcachon Lagoon, Atlantic Coast (France). Estuar. Coast. Shelf Sci. 47, 649-659.

Sakugawa, H., Handa, N., 1985. Isolation and chemical characterization of dissolved and particulate polysaccharides in Mikawa Bay. Geochim. Cosmochim. Acta 49, 1185-1193.

Smetacek, V., Hendrikson, P., 1979. Composition of particulate organic matter in Kiel Bight in relation to phytoplankton succession. Oceanol. Acta 2, 287-298.

Sottolichio, A., Castaing, P., 1999. A synthesis on seasonal dynamics of highly concentrated structures in the Gironde estuary. C. R. Acad. Sci., Sér. II 329, 895-900.

Weber, O., Jouanneau, J.M., Ruch, P., Mirmand, M., 1991. Grain-size relationship between suspended matter originating in the Gironde estuary and shelf mud-patch deposits. Mar. Geol. 96, 159-165. 